\title{
Review Article \\ Status of Biomass Derived Carbon Materials for Supercapacitor Application
}

\author{
Talam Kibona Enock, ${ }^{1,2}$ Cecil K. King'ondu, ${ }^{1,3}$ \\ Alexander Pogrebnoi, ${ }^{1}$ and Yusufu Abeid Chande Jande ${ }^{1}$ \\ ${ }^{1}$ Department of Materials and Energy Science and Engineering, The Nelson Mandela African Institution of Science and Technology, \\ P.O. Box 447, Arusha, Tanzania \\ ${ }^{2}$ Department of Physics, Mkwawa University College of Education, University of Dar es Salaam, P.O. Box 2513, Iringa, Tanzania \\ ${ }^{3}$ Department of Chemistry, South Eastern Kenya University, P.O. Box 170-90200, Kitui, Kenya
}

Correspondence should be addressed to Cecil K. Kingondu; kithongo.king'ondu@nm-aist.ac.tz

Received 24 August 2016; Revised 16 December 2016; Accepted 25 December 2016; Published 31 January 2017

Academic Editor: Sergio Ferro

Copyright (C) 2017 Talam Kibona Enock et al. This is an open access article distributed under the Creative Commons Attribution License, which permits unrestricted use, distribution, and reproduction in any medium, provided the original work is properly cited.

\begin{abstract}
Environmental concerns and energy security uncertainties associated with fossil fuels have driven the world to shift to renewable energy sources. However, most renewable energy sources with exception of hydropower are intermittent in nature and thus need storage systems. Amongst various storage systems, supercapacitors are the promising candidates for energy storage not only in renewable energies but also in hybrid vehicles and portable devices due to their high power density. Supercapacitor electrodes are almost invariably made of carbon derived from biomass. Several reviews had been focused on general carbon materials for supercapacitor electrode. This review is focused on understanding the extent to which different types of biomasses have been used as porous carbon materials for supercapacitor electrodes. It also details hydrothermal microwave assisted, ionothermal, and molten salts carbonization as techniques of synthesizing activated carbon from biomasses as well as their characteristics and their impacts on electrochemical performance.
\end{abstract}

\section{Introduction}

As climate change concerns escalate and the depletion of fossil fuels becomes more eminent, renewable energy sources have gained momentum as viable cost-effective and environment-friendly energy sources. However, most renewable energy sources are intermittent and thus need storage strategies. Currently, secondary batteries are the most used storage systems. Batteries have high energy density but low power density. Since batteries store energy chemically, both the electrolytes and electrodes undergo physicochemical changes during charging and discharging, thereby leading to low cyclability and short lifespan. These limit their applications in energy storage. Contrary to batteries, supercapacitors have high power density and cycling stability [1-3]. Nonetheless, their utility in energy storage is limited by their low energy density, relatively high effective series resistance, and high cost. This review is focused on the status of maximum energy density attained and low cost electrode materials made so far for supercapacitor electrodes.

Supercapacitors have energy density lower than that of lead acid and lithium ion batteries; however, they have higher power density and exhibit long life cycles, high cyclability, and low safety concerns compared to secondary batteries [35]; they have attracted the attention as new energy storage system. The general description of comparison between batteries, conventional capacitors, and supercapacitors is given in Table 1.

Most research studies are currently focused on increasing the energy density of supercapacitors. Supercapacitors consist of electrode materials, separators, and electrolytes. The energy density and power density of a supercapacitor can be increased by increasing both specific capacitance $(C)$ and operating voltage $(V)$ window as well as reducing the equivalent series resistance $(R)$. The voltage window can be increased by a good choice of electrolyte, while the specific 
TABLE 1: Performance comparison of different electrochemical storage systems [6].

\begin{tabular}{lccc}
\hline Parameter/current performance & Lead acid batteries & Supercapacitors & Conventional capacitor \\
\hline Energy density & $30-40 \mathrm{~W} \mathrm{~h} \mathrm{~kg}^{-1}$ & $1-10 \mathrm{~W} \mathrm{~h} \mathrm{~kg}^{-1}$ & $<0.1 \mathrm{~W} \mathrm{~h} \mathrm{~kg}$ \\
Power density & $1000 \mathrm{~W} \mathrm{~kg}^{-1}$ & $<10000 \mathrm{~W} \mathrm{~kg}^{-1}$ & $<100000 \mathrm{~W} \mathrm{~kg}^{-1}$ \\
Life cycle & 1000 & $>500000$ & $>500000$ \\
Charging time & $1-5 \mathrm{~h}$ & $0.3-30 \mathrm{~s}$ & $10^{-3}-10^{-6} \mathrm{~s}$ \\
Discharging time & $0.3-3 \mathrm{~h}$ & $0.3-30 \mathrm{~s}$ & $10^{-3}-10^{-6} \mathrm{~s}$ \\
Charging/discharging efficiency & $70-85 \%$ & $85-98 \%$ & $95 \%$ \\
Operating temperature & $-20-100^{\circ} \mathrm{C}$ & $-40-65^{\circ} \mathrm{C}$ & $-20-65^{\circ} \mathrm{C}$ \\
\hline
\end{tabular}

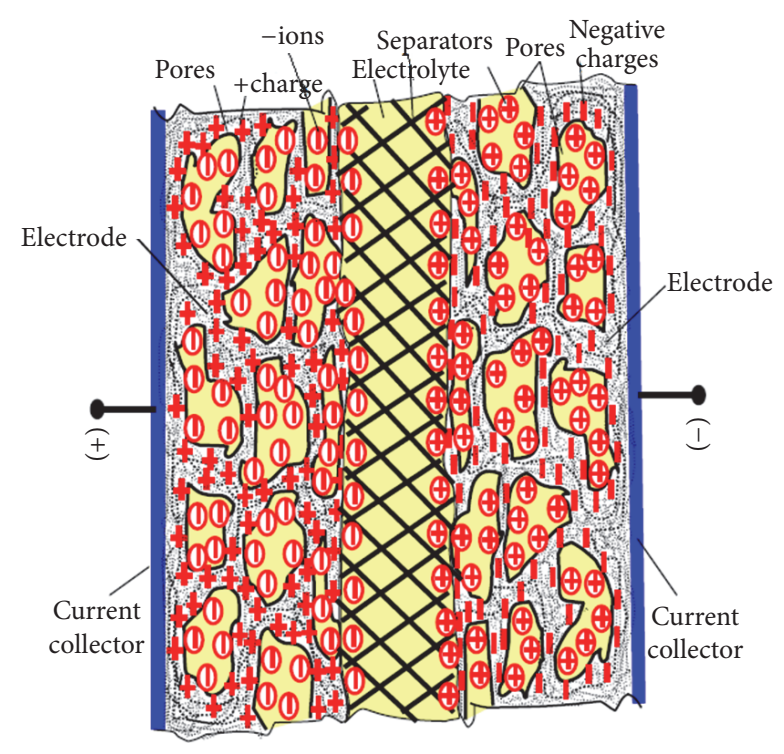

FIGURE 1: Schematic representation of a supercapacitor cell (reproduced with the permission from the author [7]).

capacitance of the supercapacitor can be improved by either finding new electrode materials or optimizing the existing materials [4] in terms of interconnected porosity, electrical conductivity, and surface area among others.

In principal, supercapacitors store energy based on two capacitive behaviors: Electrical Double-Layer (EDL) capacitance and pseudocapacitance. While the former is due to electrostatic interaction, pseudocapacitance is due to faradic phenomenon involving fast and reversible electrochemical reactions. In pseudocapacitance, the redox reactions are between the electrolyte and the electrode materials. The products of redox reactions are therefore electrons which are then transferred through electrode/electrolyte interfaces [4]. The EDL has the advantage that electrochemical kinetics is not limited by polarization resistance and no swelling of the active materials is experienced. The energy is stored in two porous electrodes with current collector on each electrode; the stored energy is released when charges accumulated at the electrode discharge as shown in Figure 1. The number of charges stored in the electrode is proportional to the surface of the electrode, and energy stored is proportional to the amount of charge stored. Therefore, materials with high surface area are regarded as good candidates for supercapacitor electrode.

The improvement of supercapacitor performance can be attributed through discovery of new electrode materials, understanding of ions behavior in small pores, and designing hybrid system by combining faradic and capacitive electrodes.

\section{Materials for Supercapacitor Electrodes}

2.1. Carbon Materials for Supercapacitor Electrodes. Different materials have been investigated as electrode materials for supercapacitors, the materials conducting polymers, porous materials, and metal oxides. The parameters like optimum pore size and high surface area of the electrode materials for a given electrolyte determine the performance of supercapacitor in terms of power density and energy storage capability [8]. High surface area is important because the energy in electrochemical storage systems is stored on the surface, while the pores size facilitates the storage and transport of charges. Carbon materials are more attractive because they are available in different forms (such as fibers, powders, nanotubes, and nanospheres) and are rich in dimensionality [2].

The microstructure and surface chemistry of carbon can be adjusted easily, thus altering the electrochemical performance of the material [9]. It has been reported further that carbon materials based electrodes have reasonably high electrical conductivity, high thermal stability, excellent corrosion resistance, tailorable pore distribution, relatively high surface area, low cost, and satisfactory compatibility with a number of materials in making composites $[2,10]$.

2.1.1. Activated Carbons. Porous carbon is prepared through different methods depending on the intended application. One of the mainly used methods for supercapacitors is activating the carbon either chemically or physically. Activated carbon is synthesized through carbonization of carbon precursor followed by activation at temperature around 600$800^{\circ} \mathrm{C}$ in an inert atmosphere. The type of carbon precursor is one of the determining factors of the properties of the activated carbons.

Physical activation involves two processes; first is pyrolysis, in an inert atmosphere, of the carbon precursor at temperatures between 400 and $1000^{\circ} \mathrm{C}$, and second is gasification, where the porosity and surface area are developed using oxidizing gases such as carbon dioxide or air and 
steam between 700 and $1200^{\circ} \mathrm{C}$ [11-13]. Pyrolysis is intended to remove all volatile materials in the precursor, while gasification opens some closed pores by burning away the tar-like pyrolysis product within the pores. Furthermore, the active sites increase as more organics are burned away by oxidizing agent [14].

In contrast, chemical activation involves using potassium hydroxide [15-19], sodium hydroxide [20, 21], phosphoric acid [22-24], zinc chloride [19, 25, 26], and nitric acid and sulphuric acid [27]. Phosphoric acid and zinc chloride act as dehydrating agent, while potassium hydroxide is an oxidant. In comparison to physical activation method, chemical activation has the following advantages: (1) the pores are well developed and pore size is controllable, (2) materials with high surface area are produced, (3) yield carbon is high, (4) it involves only one step, and (5) it has lower pyrolysis temperature [14]. For energy storage applications such as supercapacitors, the first two advantages strengthen the use of chemical activation.

For $\mathrm{KOH}$ activation, which is mainly applied to supercapacitor electrode materials preparation, the ratio of alkali/ carbon varies from $1: 1$ to $5: 1$ depending on the concentration of the impregnating solution [19]. The excess $\mathrm{KOH}$ is removed by suspending the activated carbon in $0.1 \mathrm{M} \mathrm{HCl}$ solution and then washed with water until $\mathrm{pH}$ of 7 is achieved. Samples are then oven-dried ready to be used in electrochemical testing and other characterizations. Activated carbons sometimes exhibit a high Brunauer-Emmet-Teller (BET) surface area which exceeds $2500 \mathrm{~m}^{2} \mathrm{~g}^{-1}$ and pore volume which is close to $2 \mathrm{~cm}^{3} \mathrm{~g}^{-1}$ [28]. The majority of pores in the activated carbon are micropores and only small number of mesopores; this is because at higher temperatures most of mesopores break and the pore diameter decreases [29].

Due to the availability, cheap cost, and ability to become highly porous after carbonization, different kinds of biomass feedstock have been used as precursors for carbon. Understanding the biomass derived porous carbon materials and their properties is of importance in order to match the carbon properties with those of supercapacitors. Porous carbon materials are classified depending on their pore width; those with $<2 \mathrm{~nm}$ pore width are classified as microporous, those with 2 to $50 \mathrm{~nm}$ pore width are classified as mesoporous, while those with pore width greater than $50 \mathrm{~nm}$ are classified as macroporous $[4,30]$. For supercapacitors application, both micropores and mesopores play an important role. Micropores are important in storing charges, while mesopores store and facilitate charge transfer. The reported surface areas and capacitance exhibited by different biomass derived carbon materials are as described in Table 2. Generally, the higher the specific surface area of activated carbon is, the higher the active surface area is. However, despite high specific surface areas attained for activated carbons, that is, around 2500 to $3000 \mathrm{~m}^{2} \mathrm{~g}^{-1}$, some activated carbons exhibit low specific capacitance as depicted in Table 1 . This might be due to wide pore size distributions, pore size, type of the electrolyte used, scan rate, mass, or surface area of the electrode. Small pore size of $0.68 \mathrm{~nm}$ limits the electrolyte from accessing the entire active surface area of activated carbon [31].
Though it is suggested that the specific capacitance and BET surface area of activated carbon have close correlation, it is not the case for all carbon precursors as shown in Figure 2. The relationship between surface area and capacitance is not always obvious due to the fact that capacitance is contributed by other factors such as pore size, electrical conductivity, and pore distribution and interconnectivity $[31,54]$.

The increase in the fraction of pore size which cannot be accessed by the electrolyte (when the average pore size is below $0.68 \mathrm{~nm}$ ) in organic electrolyte is expected to decrease the capacitance [31]; however, an anomalous behavior is observed, where the capacitance increases with the pores having pore size of less than $1 \mathrm{~nm}$ in acetonitrile organic electrolyte [63]. Figure 2 shows that there is no direct correlation between capacitance and the pore size of the electrode materials. Actually many factors have a huge impact on the capacitance: the materials surface chemistry, method of preparing electrodes, the electrolyte used, and electrode testing method.

Apart from plant wastes, animal wastes have been studied as potential carbon precursors for supercapacitors electrode. To date, cow dung [55], animal bones [56], chicken egg membranes [58], and human hair [59, 64] have been reported in the literature. The physical and electrochemical properties of these wastes are described in Table 3.

In order to know how fast energy can be stored in a unit volume of materials volumetric capacitance is of importance. Factors affecting the volumetric capacitance were reviewed by Wang and coworkers [65]. Surprisingly, a good number of researches overlook this parameter when evaluating the suitability of materials for supercapacitor electrodes application. At the same time, few authors had taken into account the volumetric capacitance for characterizing the biomass derived carbon. Xie et al. [66] composited corn straw and soy protein to obtain a surface area of $1412.9 \mathrm{~m}^{2} \mathrm{~g}^{-1}$ with gravimetric capacitance and volumetric capacitance of $321.1 \mathrm{~F} \mathrm{~g}^{-1}$ and $213 \mathrm{~F} \mathrm{~cm}^{-3}$, respectively, at $20 \mathrm{~A} \mathrm{~g}^{-1}$ in $6 \mathrm{M} \mathrm{KOH}$. When soybean was chemically activated after carbonization and tested for supercapacitor electrodes, gravimetric capacitance and volumetric capacitance of $260 \mathrm{~F} \mathrm{~g}^{-1}$ and $210 \mathrm{~F} \mathrm{~cm}^{-3}$, respectively, was obtained in $\mathrm{H}_{2} \mathrm{SO}_{4}$ [67]. In the same study, gravimetric capacitance and volumetric capacitance of $176 \mathrm{Fg}^{-1}$ and $102 \mathrm{~F} \mathrm{~cm}^{-3}$, respectively, was obtained in $\mathrm{Li}_{2} \mathrm{SO}_{4}$ electrolyte. It was further revealed that volumetric capacitance decreased with activating temperature increase and it was an opposite trend for the gravimetric capacitance. The low volumetric capacitance at high temperature may be caused by low conductivity of biomass derived carbons as the high surface area decreases the density sites. Eukaryotic organism (Auricularia) was used as precursor for synthesizing porous carbon which exhibited bulk density of $0.96 \mathrm{~g} \mathrm{~cm}^{-3}$, surface area of $1103 \mathrm{~m}^{2} \mathrm{~g}^{-1}$, volumetric capacitance of $360 \mathrm{~F} \mathrm{~cm}^{-3}$, and cyclic stability of $99 \%$ after 10000 cycles were obtained [68]. It has been reported that the heteroatom functional groups of biomass derived carbon enhance volumetric capacitance. For example, high volumetric capacitance of $468 \mathrm{~F} \mathrm{~cm}^{-3}$, high packing density of $1.1 \mathrm{~g} \mathrm{~cm}^{-3}$, and capacitance retention of 


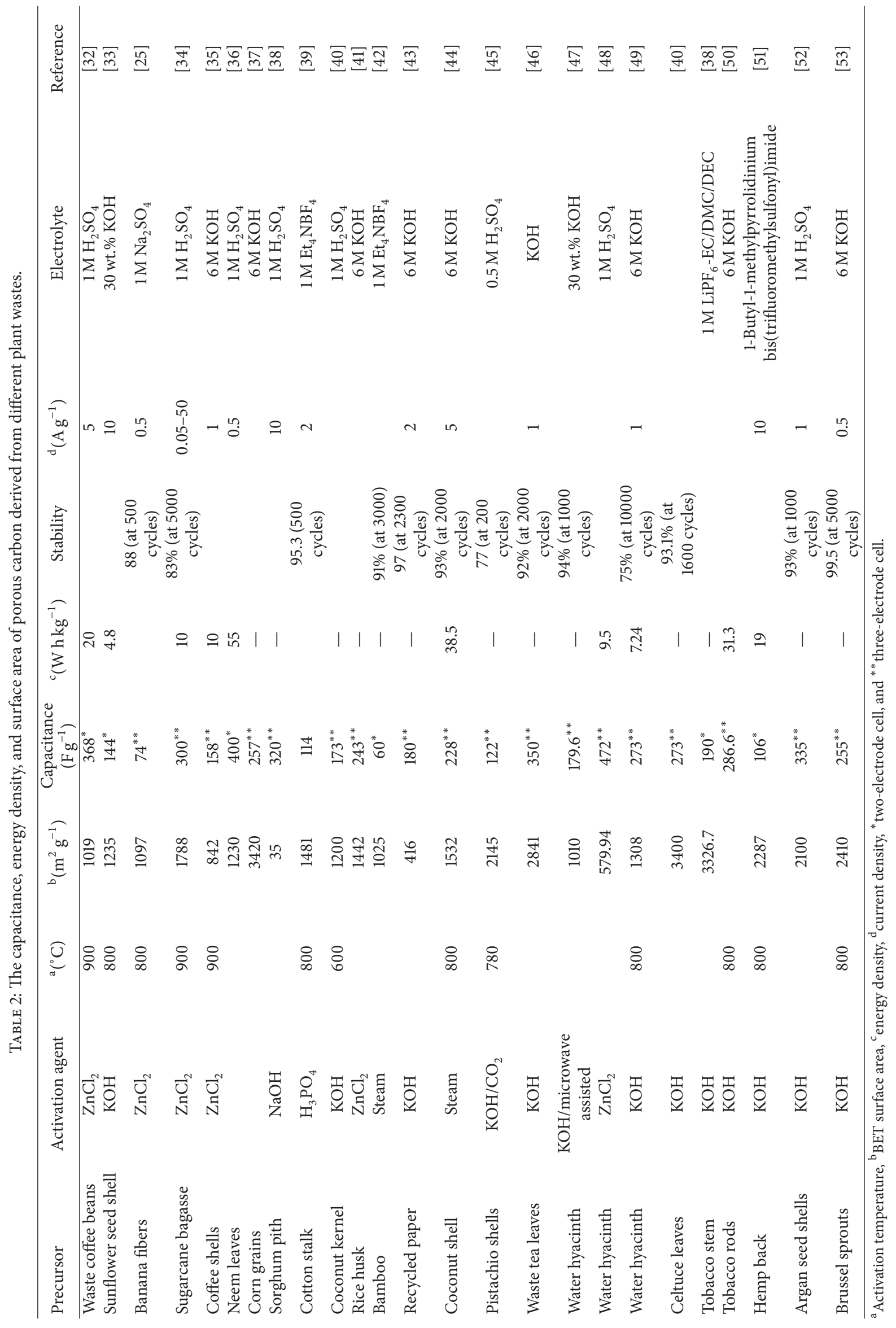




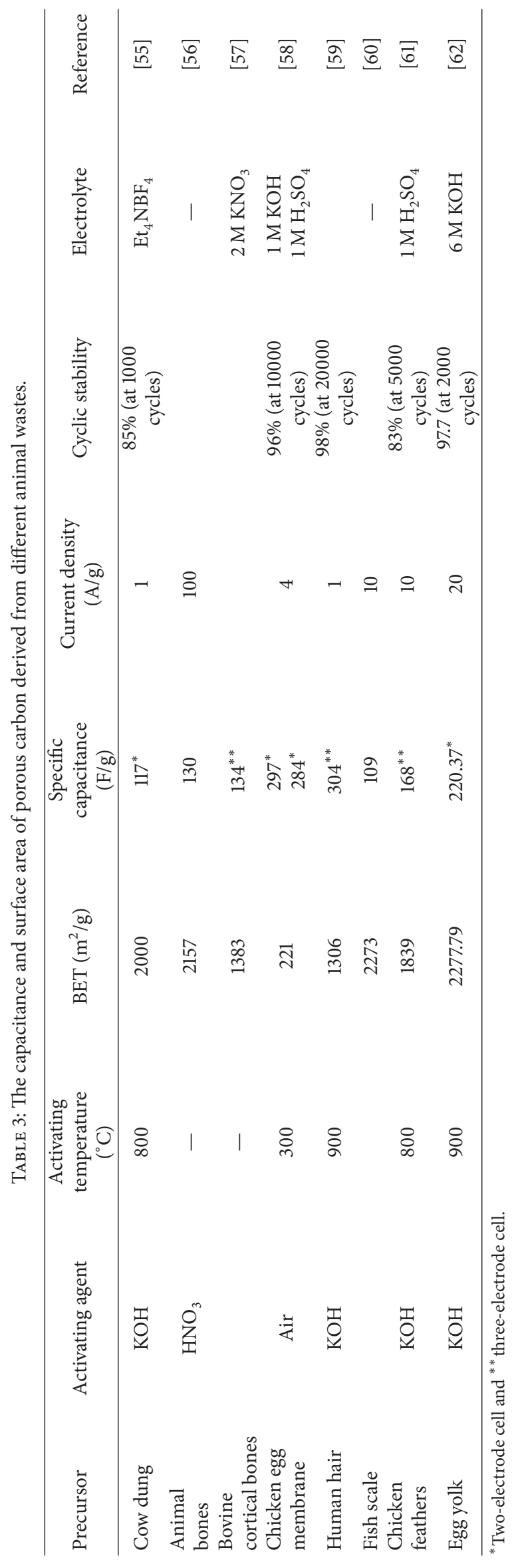




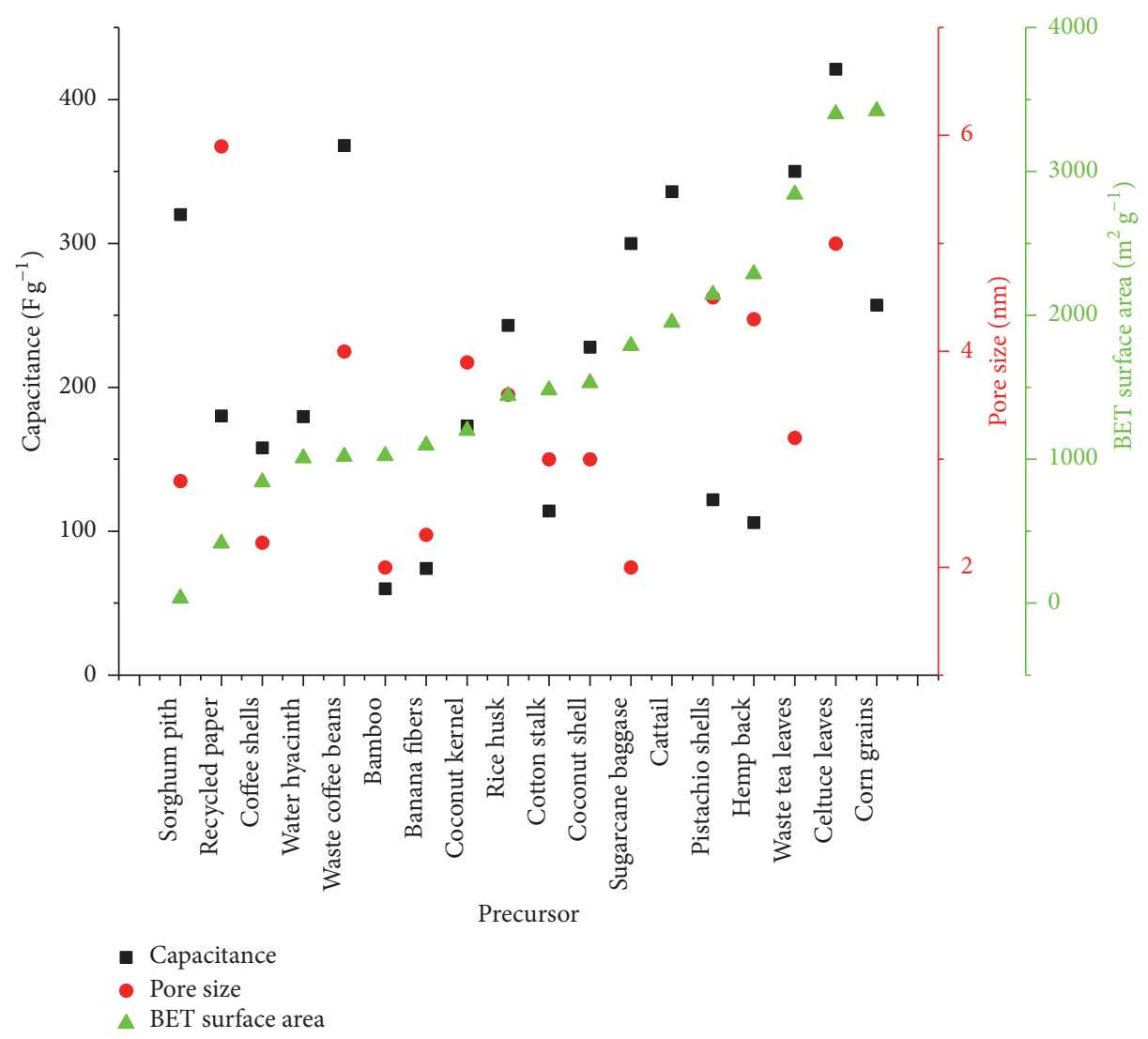

FIGURE 2: Variation of reported capacitance, pore size, and BET surface area of activated carbon materials derived from different plant precursors.

91\% after 10000 cycles were achieved when functionalized porous carbon was synthesized from soybean [69].

The differences in the reported capacitance are attributed to the method of testing. It is reported that the three-electrode cell gives higher capacitance results compared to its twoelectrode counterpart [70]; thus there is a need to establish standardized best practice of determining the capacitance of the material. Although the testing method may be the same for different studies, differences in mass loading, electrode thickness, type and amount of binder, and type of current collector have huge impact on the capacitance obtained.

The presence of surface functionalities and heteroatoms such as $\mathrm{O}$ and $\mathrm{N}$ on carbon also play an important role in the pseudocapacitance behavior of the electrode [71, 72]. Oxygen comes from both the activation and biomass itself, while nitrogen can come from the biomass or is introduced into the carbon through doping [73]. It has been reported that the capacitance of $\mathrm{O}$ and $\mathrm{N}$ containing carbonized chicken egg shell membrane is $297 \mathrm{~F} \mathrm{~g}^{-1}$ with cyclic efficiency of $97 \%$ after 10000 cycles [58]. The activated carbon from the same precursor has specific capacitance of $203 \mathrm{~F} \mathrm{~g}^{-1}$, despite the fact that the specific surface area was 7 times higher than carbonized chicken egg shell membrane. It has been reported also that oxygen- and nitrogen-rich activated carbon enhances the specific capacitance differently. While oxygen-rich activated carbon exhibits lower capacitance because the electrolyte diffusion into pores is hindered by carboxyl surface, the nitrogen-rich one exhibits higher capacitance [52, 74]. Furthermore, it is reported that the adsorption and transport of electrolyte ions are enhanced by doping activated carbon with heteroatom such as sulphur $[72,75,76]$. Heteroatom increases the wettability of the electrode which in turn increases the capacitance; thus studies on doping different heteroatoms on the activated carbon are emphasized.

Microwave assisted heat treatment is one of the methods of activating carbon for supercapacitor applications. It is a facile, controllable, fast, and energy-saving technique. When carbon xerogel was activated chemically using microwave radiation, microspores and mesopores were produced at a time range between 6 and $30 \mathrm{~min}$ [77]. Although microwave radiation method produces well-modified surface chemistry of activated carbons, it causes significant reduction in micropore volume and size $[78,79]$.

Hydrothermal carbonization (HTC) is another way of producing porous carbon for supercapacitor electrodes. In this method, a mixture of water and carbon precursor is thermally treated at temperature ranges of $150-300^{\circ} \mathrm{C}$ and $300-800^{\circ} \mathrm{C}$ for low and high temperature HTC, respectively $[80,81]$. Apart from high solid carbon yield, the method also reduces the oxygen and hydrogen content $[82,83]$ and produces materials with very high BET surface area. Jain and coworkers obtained BET and mesopore areas of up to 2440 
TABLE 4: The preparation method and properties of porous carbon derived from coconut shells.

\begin{tabular}{lcccc}
\hline Preparation method & BET surface area $\left(\mathrm{m}^{2} \mathrm{~g}^{-1}\right)$ & Capacitance $\left(\mathrm{Fg}^{-1}\right)$ & Energy density $\left(\mathrm{Wh} \mathrm{kg}^{-1}\right)$ & Reference \\
\hline CPS & 1559 & 228 & 38 & 8.5 \\
OHCZ & 2440 & 246 & - & {$[44]$} \\
CZ & 1266 & - & - & - \\
CZP & 2114 & - & {$[87]$} \\
\hline
\end{tabular}

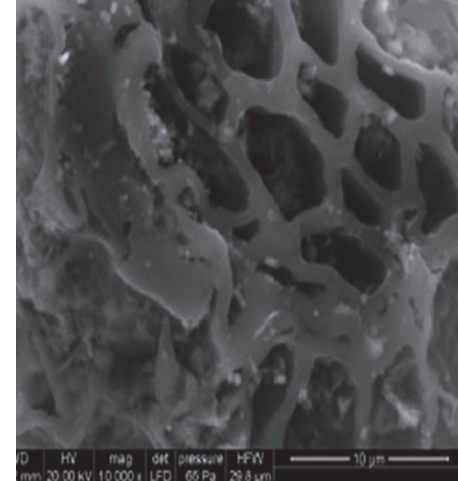

(a) SEM micrography for water hyacinth derived carbon [48]

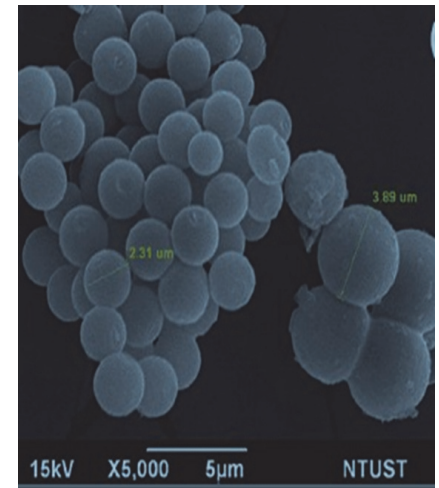

(b) SEM images of water hyacinth derived carbon activated using $\mathrm{ZnCl}_{2}$ [47]

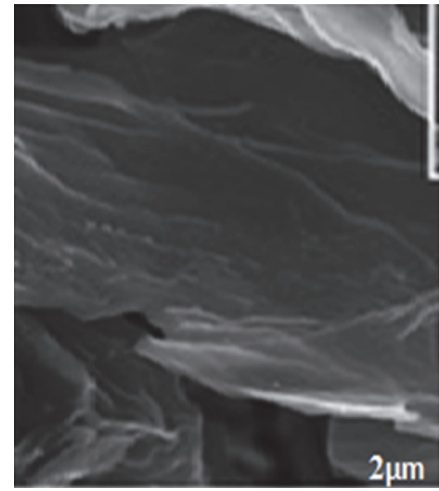

(c) SEM images for water hyacinth activated with $\mathrm{KOH}$ [49]

FIGURE 3: SEM morphologies of porous carbon derived from water hyacinth through different routes.

and $1121 \mathrm{~m}^{2} \mathrm{~g}^{-1}$, respectively, after hydrothermal treatment of coconut shells with $\mathrm{ZnCl}_{2}$ and $\mathrm{H}_{2} \mathrm{O}_{2}$ at temperature of $275^{\circ} \mathrm{C}$ [84]. When the same material was chemically activated using $\mathrm{ZnCl}_{2}$ at $500^{\circ} \mathrm{C}$ for $3 \mathrm{~h}$ by Azevedo et al. [85], BET surface area of $1266 \mathrm{~m}^{2} \mathrm{~g}^{-1}$ was obtained. Elaigwu and Greenway [86] compared the chemical and structural properties of carbon derived from Prosopis africana waste plant material prepared by conventional hydrothermal and microwave assisted hydrothermal carbonization. They found that that microwave assisted hydrothermal carbonization was faster in decomposing Prosopis africana as the degree of structure alteration was achieved within a short time when compared to the conventional approach [86].

The comparison can easily be depicted in Table 4, where CPS represents combined pyrolysis and steam activation, OHCZ represents optimal hydrothermal treatment and chemical activation with $\mathrm{ZnCl}_{2}, \mathrm{CZ}$ represents chemical activation with $\mathrm{ZnCl}_{2}$, and CZP represents chemical activation with $\mathrm{ZnCl}_{2}$ followed by physical activation. It is worth mentioning that the precursor for all the above-mentioned methods is the same (coconut shell).

The porosity of the carbon is also influenced by type of activation; for example, when firewood and pistachio were carbonized and activated using steam and $\mathrm{KOH}, \mathrm{KOH}$ activated carbon had $9.2-15.3 \%$ mesopores, while steam activated carbon had $33.3-49.5 \%$ [88]. On the other hand, the surface capacitance has been reported to increase with the increase in mesopore content [89].
Electrochemical performances of different biomass derived carbon materials have also shown strong correlation between capacitance, morphology, and the method used to prepare the carbon. For instance, water hyacinth (WH) has been used to prepare porous carbon by different authors; however, their results differ probably due to their methods, morphology obtained, and/or surface area [47, 48, 90]. Senthilkumar and coworkers [48] activated the WH derived carbon using $\mathrm{ZnCl}_{2}$ and obtained the porous carbon with no particular shape (Figure 3(a)); the specific capacitance of $472 \mathrm{Fg}^{-1}$ was obtained in aqueous electrolyte $\mathrm{H}_{2} \mathrm{SO}_{4}$. Kurniawan and coworkers [47] developed microspheres (Figure 3(b)) through subcritical water carbonization followed by $\mathrm{KOH}$ activation and microwave treatment; the specific capacitance was $179.6 \mathrm{Fg}^{-1}$ in aqueous electrolyte. From the same carbon precursor, Syarif and Pardede [90] developed porous carbon through hydrothermal treatment followed by microwave pyrolysis, the carbon has a shining bead chain and waffle structures with cavities, the capacitance obtained in aqueous electrolyte $\left(\mathrm{H}_{2} \mathrm{SO}_{4}\right)$ was $0.0218 \mathrm{Fg}^{-1}$, no conductive and activating agent was added, and the capacitance increased 10 times when graphite was added to the carbon in the ratio of 3:7. Carbon sheets (Figure 3(c)) were produced by $\mathrm{Wu}$ and coworkers [49] through acid $(\mathrm{HCl})$ treatment and pyrolytic carbonization and $\mathrm{KOH}$ activation of water hyacinth biomass. Micropores and mesopores were developed which in electrochemical testing achieved specific capacity of $273 \mathrm{~F} \mathrm{~g}^{-1}$ at current density of $1 \mathrm{~A} \mathrm{~g}^{-1}$. 
TABLE 5: Specific capacitances and surface area of porous carbon synthesized through salt carbonization of different of different biomasses.

\begin{tabular}{|c|c|c|c|c|c|c|c|}
\hline Precursor & Salt & $\begin{array}{c}\text { Carbonization } \\
\text { temperature }\end{array}$ & $\begin{array}{c}\text { Surface area } \\
\left(\mathrm{m}^{2} \mathrm{~g}^{-1}\right)\end{array}$ & $\begin{array}{c}\text { Specific } \\
\text { capacitance }\left(\mathrm{Fg}^{-1}\right)\end{array}$ & $\begin{array}{c}\text { Current } \\
\text { density }\left(\mathrm{Ag}^{-1}\right)\end{array}$ & Electrolyte & Reference \\
\hline Firewood & $\mathrm{Na}_{2} \mathrm{CO}_{3}-\mathrm{K}_{2} \mathrm{CO}_{3}$ & 850 & 818 & 189 & 0.5 & $1 \mathrm{M} \mathrm{H}_{2} \mathrm{SO}_{4}$ & [98] \\
\hline $\begin{array}{l}\text { Chitosan from shells } \\
\text { of shrimps }\end{array}$ & $\mathrm{ZnCl}_{2}$ & 600 & 1582 & 256 & 0.5 & $6 \mathrm{M} \mathrm{KOH}$ & [99] \\
\hline Peanut shells & $\mathrm{Na}_{2} \mathrm{CO}_{3}-\mathrm{K}_{2} \mathrm{CO}_{3}$ & 700 & & 160 & 1 & $1 \mathrm{M} \mathrm{H}_{2} \mathrm{SO}_{4}$ & {$[100]$} \\
\hline Bamboo shells & $\mathrm{Na}_{2} \mathrm{CO}_{3}-\mathrm{K}_{2} \mathrm{CO}_{3}$ & 850 & 843 & 204 & 1 & $1 \mathrm{M} \mathrm{H}_{2} \mathrm{SO}_{4}$ & {$[101]$} \\
\hline Boiled coffee beans & $\begin{array}{c}\mathrm{Na}_{2} \mathrm{CO}_{3}-\mathrm{K}_{2} \mathrm{CO}_{3} \\
\mathrm{CaCl}_{2}\end{array}$ & $\begin{array}{l}800 \\
850\end{array}$ & $\begin{array}{l}436 \\
550\end{array}$ & $\begin{array}{c}161 \\
93.4\end{array}$ & $\begin{array}{l}0.5 \\
0.4\end{array}$ & $1 \mathrm{M} \mathrm{MeEt}_{3} \mathrm{NBF}_{4}$ & [102] \\
\hline
\end{tabular}

It was further shown that the capacitance of water hyacinth derived carbon electrode increased from 472 to $912 \mathrm{~F} \mathrm{~g}^{-1}$ when potassium iodide $(0.08 \mathrm{M} \mathrm{KI})$ was added to $1 \mathrm{M} \mathrm{H}_{2} \mathrm{SO}_{4}$ electrolyte, signifying the effect of electrolyte [48]. The addition of $\mathrm{KI}$ in the electrolyte enhanced the capacitance because $\mathrm{KI}$ can produce redox pairs $\left(3 \mathrm{I}^{-} / \mathrm{I}_{3}{ }^{-}, 2 \mathrm{I}_{3}{ }^{-} / 3 \mathrm{I}_{2}\right.$, and others) during electrochemical processes, which in turn could easily access the small micropores and mesopores. Through hydrothermal treatment, interconnected graphitic carbon nanosheets can also be produced. For example, Wang and coworkers [51] developed nanosheets from hemp back fibers with high specific surface area up to $2287 \mathrm{~m}^{2} \mathrm{~g}^{-1}$ with capacitance retention of $72-92 \%$ at current density of $100 \mathrm{Ag}^{-1}$. The study also revealed that the materials were stable at different temperatures of 20,60 , and $100^{\circ} \mathrm{C}$.

Ionothermal carbonization is another method of synthesizing porous carbon from biomass, where only one step is required. The ionic liquids possess high chemical and thermal stability, low melting point, electrical and ionic conductivity, and negligible vapor pressure. This method has been reported to produce carbon with high surface area and large pore volume [91]. A high surface area $\left(2160 \mathrm{~m}^{2} \mathrm{~g}^{-1}\right)$ and total pore volume of $1.74 \mathrm{~cm}^{3} \mathrm{~g}^{-1}$ were obtained when carbon was synthesized from glucose [92]. In this study, $\mathrm{KCl}-\mathrm{ZnCl}_{2}$ system molar ratio was varied to act as template/solvent during carbonization; it was further revealed that the higher content of $\mathrm{KCl}$ increased the pore size and surface area. The gravimetric capacitance obtained was $206 \mathrm{Fg}^{-1}$. Lin et al. [93] synthesized microporous and mesoporous carbon from fructose through one-step ionothermal method using iron. The surface area of $1200 \mathrm{~m}^{2} \mathrm{~g}^{-1}$, pore volume of $0.8 \mathrm{~cm}^{3} \mathrm{~g}^{-1}$, and specific capacitance of $245 \mathrm{Fg}^{-1}$ at current density of $1 \mathrm{~A} \mathrm{~g}^{-1}$ were obtained. In the study different masses of fructose were dispersed in $10 \mathrm{~mL}$ of 1-butyl-3-methylimidazolium tetrachloroferrate $[\mathrm{Bmim}]\left[\mathrm{FeCl}_{4}\right]$. $[\mathrm{Bmim}]\left[\mathrm{FeCl}_{4}\right]$ was used as template, solvent, and catalyst with advantage that it can be reused after recovery. Other biomass derived structured carbons were produced ionothermally from carbohydrates [94], sugar bagasse [95], and bamboo [96]. However, these carbons were not tested for supercapacitor applications.

Molten salt carbonization (MSC) is another method of synthesizing porous carbon from biomass, in which the molten salt cracks the large molecules of biomass. In MSC, the salt involved is melted at its melting point; then biomass is immersed into the molten salt and carbonized at temperature greater than $400^{\circ} \mathrm{C}$ in inert atmosphere. After carbonization, the furnace is cooled to room temperature and the product is washed with $\mathrm{HCl}$ and distilled water in order to remove salts within the product. It is reported that the particle size of the biomass alters the yield [97]. Table 5 shows different biomasses carbonized in different salts and the obtained gravimetric capacitance and specific surface area. It is difficult to tell the best biomass or salt because the carbonization temperature and electrolyte for electrochemical testing are different.

2.1.2. Carbon Aerogel Derived from Biomasses. Carbon aerogel is another form of carbon used in supercapacitor electrodes, whereby the porous carbon is produced through pyrolysis of organic aerogels [103]. The porosity is a result of a combination of interconnected colloidal particles. The porous carbon materials can be composites, monoliths, powders, microspheres, or thin films. The aerogels carbon materials have been reported to exhibit higher surface area compared to activated carbon [104]. Carbon fiber aerogels with surface areas ranging from 1536 to $2436 \mathrm{~m}^{2} \mathrm{~g}^{-1}$ and pore size ranging between 1.0 and $4.0 \mathrm{~nm}$ exhibited high specific capacitance of $282 \mathrm{Fg}^{-1}\left(1 \mathrm{Ag}^{-1}\right)$ in $6 \mathrm{M} \mathrm{KOH}$ electrolyte $[51,105]$.

A green technology of fabricating sponge-like carbonaceous hydrogels/aerogels from watermelon was developed by $\mathrm{Wu}$ and coauthors [106]. The study revealed that watermelon can be polymerized and carbonized to form carbonaceous mesosphere and nanofibers during hydrothermal reaction.

The cellulose from bagasse has been utilized as the raw materials for carbon aerogel. Two procedures were followed. Firstly, cellulose was dissolved in a solvent mixture of $\mathrm{NaOH} /$ urea/ $\mathrm{H}_{2} \mathrm{O}$ and super cooling in $-12^{\circ} \mathrm{C}$. Secondly, the gels were regenerated in water at room temperature and then frozen at $-80^{\circ} \mathrm{C}$ [107]. The synthesized aerogels exhibited large channels with average diameter in the range of $50-100 \mathrm{~nm}$. The specific capacitance of the assembled supercapacitor was $142.1 \mathrm{~F} \mathrm{~g}^{-1}$ at current density of $0.5 \mathrm{~A} \mathrm{~g}^{-1}$.

In another study, the 3D N-doped carbonaceous aerogels were produced through one-pot hydrothermal synthesis using the soft tissue biomass of watermelon as a source of aerogel. The method produced specific capacitance of $281 \mathrm{~F} \mathrm{~g}^{-1}$. It has been reported that nitrogen doped porous carbon possesses higher specific capacitance compared to the undoped porous carbon because of pseudocapacitive behavior of nitrogen functional groups [108]. 
TABLE 6: The capacitance, energy density, and stability of different composites.

\begin{tabular}{|c|c|c|c|c|c|c|c|c|}
\hline Carbon precursor & Composite & $\begin{array}{l}\text { Method of } \\
\text { preparation }\end{array}$ & $\begin{array}{l}\text { Capacitance } \\
\quad\left(\mathrm{Fg}^{-1}\right)\end{array}$ & $\begin{array}{c}\text { Energy } \\
\text { density } \\
\text { (Wh/kg) }\end{array}$ & $\begin{array}{l}\text { Power } \\
\text { density } \\
(\mathrm{W} / \mathrm{kg}) \\
\end{array}$ & Stability & $\begin{array}{l}\text { Current } \\
\text { density } \\
\left(\mathrm{Ag}^{-1}\right)\end{array}$ & Reference \\
\hline Flax textiles & $\begin{array}{c}\mathrm{MnO}_{2} \text { nanosheet/carbon } \\
\text { cloth }\end{array}$ & In situ & 683.73 & 46.54 & 45500 & $\begin{array}{c}94 \% \text { (at } \\
1000 \text { cycles) }\end{array}$ & 2 & [118] \\
\hline Kenaf stem & Porous carbon $/ \mathrm{MnO}_{2}$ & & 416 & 17.3 & 198-3175 & $\begin{array}{c}86 \% \text { (at } \\
1000 \text { cycles) }\end{array}$ & 16 & [119] \\
\hline Mollusc shell & $\begin{array}{c}\text { Macroporous } \\
\text { carbon/ } / \mathrm{NiCO}_{2} \mathrm{O}_{4}\end{array}$ & & 1696 & 8.47 & & $\begin{array}{c}88 \% \text { (at } \\
2000 \text { cycles) }\end{array}$ & - & [120] \\
\hline
\end{tabular}

2.2. Metal Oxides and Carbon/Metal Oxide Composites. The energy density of a carbon material is a function of both capacitance and electrical conductivity exhibited by the electrode. Though activated carbons have low capacitive behavior, their high electrical conductivity qualifies them for supercapacitor electrode. On the other hand, transition metal oxides (TMO) have high capacitance but low conductivity. Metal oxide electrodes have poor cyclic stability due to the cracks caused by the strain in the metal oxide during charging and discharging processes [109].

Studies on the application of ruthenium oxide $\left(\mathrm{RuO}_{2}\right)$ [110], manganese (IV) oxide $\left(\mathrm{MnO}_{2}\right)$, cobalt (II, III) oxides $\left(\mathrm{Co}_{3} \mathrm{O}_{4}\right)$, nickel oxide (NiO) [111], molybdenum trioxide $\left(\mathrm{MoO}_{3}\right)$, molybdenum (IV) oxide $\left(\mathrm{MoO}_{2}\right)$, and vanadium nitride $(\mathrm{VN})$ as the electrochemical active materials have been conducted [112]. Though $\mathrm{RuO}_{2}$ has excellent capacitance, its high cost, toxic nature, and low porosity limit its application. Nickel oxide, cobalt oxide, and manganese dioxide are inexpensive and thus derive interest in improving their electrochemical performance.

Efforts have been made to composite biomass derived carbon and metal oxides so as to capture the strength of the two in increasing the energy density without sacrificing the high power density. An important consideration related to porous carbon/metal oxide is their performance in terms of capacitance, stability, power, and energy densities. Sawdust derived carbon was directly composited with $\mathrm{FeCl}_{3}$ and $\mathrm{TiCl}_{2}$ and the composite was oxidized in concentrated nitric acid [113]. From this study, it was revealed that the metal oxide loading and surface functionalities affect the voltammograms shapes. Moreover, with exception of $\mathrm{RuO}_{2}$, the conductivity of other transition metal oxides is poor, resulting in low power and energy density. This is because the IR loss is very large at high current density caused by both the charge transfer resistance of the electrode and sheet resistance [114].

Based on its pseudocapacitive behavior, $\mathrm{RuO}_{2}$ has been found to be an excellent electrode. $\mathrm{RuO}_{2} /$ carbon composite prepared by Lin et al. [115] exhibited a specific surface area of $520 \mathrm{~m}^{2} \mathrm{~g}^{-1}$ at current density of $1 \mathrm{~A} \mathrm{~g}^{-1}$ and specific capacitance of $256 \mathrm{~F} \mathrm{~g}^{-1}$. In another study, colloidal method was used to prepare a nanostructured composite of $\mathrm{RuO}_{2}$ and carbon. The specific capacitance of $\mathrm{RuO}_{2}$ /carbon composite electrode $\left(40 \% \mathrm{RuO}_{2}\right)$ was reported to be $407 \mathrm{Fg}^{-1}$ as calculated from cyclic voltammetry. When the contribution of double-layer capacitance resulting from carbon was subtracted, the specific capacitance of $\mathrm{RuO}_{2} \cdot \chi \mathrm{H}_{2} \mathrm{O}$ was approximately $863 \mathrm{Fg}^{-1}$. The volumetric capacitance of the composite increased as the weight of $\mathrm{RuO}_{2}$ increased to $40 \mathrm{wt} . \%$ and then dropped due to increased particle size of $\mathrm{RuO}_{2}$ [116]. However, due to the high cost of $\mathrm{RuO}_{2}$, its practical application in supercapacitors is limited; thus exploitation of alternative metal oxides is very necessary.

The specific area and specific capacitance have been reported to increase when carbon is composited with metal oxide. Specific surface area of $\mathrm{NiO} /$ carbon composite increased from $150 \mathrm{~m}^{2} \mathrm{~g}^{-1}$ for $\mathrm{NiO}$ to $700 \mathrm{~m}^{2} \mathrm{~g}^{-1}$ when $\mathrm{NiO}$ was composited with carbon, while the specific capacitance increased from 20 to about $100 \mathrm{~F} \mathrm{~g}^{-1}$ [117].

Apart from activated carbon being composited with metal oxides, attempts have been made to composite aerogels made from bagasse with $\mathrm{Fe}_{2} \mathrm{O}_{3}$. The aerogel/ $/ \mathrm{Fe}_{2} \mathrm{O}_{3}$ composite exhibited high specific capacitance of $333.1 \mathrm{Fg}^{-1}$ at current density of $1 \mathrm{Ag}^{-1}$ with excellent cyclic stability of $96 \%$ at 1000 cycles [106]. The variation of specific capacitance, energy density, and power density of different composites can be seen in Table 6.

It has been shown that the composition with lowest metal oxide content displays the highest capacitance. This is attributed to the fact that, at high metal oxide content, the fraction of accessible active surface area is low and the resistance is high.

2.3. Activated Carbon/Conducting Polymers. Conducting polymers have also been used as electrode materials for supercapacitors due to their good electrochemistry, simplicity in doping, and easy preparation. However, during the charge-discharge cycles, the sites in polymers responsible for redox are not stable; thus resulting in low life cycle of the conducting polymers electrode. Wang and coworkers coated activated carbon with polyaniline (PANI) through polymerization of aniline using cyclic voltammetry. It was revealed that the PANI electrode and PANI-activated carbon composite maintained cyclic stability of 65 and $92 \%$, respectively, at 50 cycles and high specific capacitance of $587 \mathrm{~F} \mathrm{~g}^{-1}$ [121].

Lin and Teng demonstrated that the capacitance of a carbon electrode can be increased by at least $50 \%$ if $5 \mathrm{wt} . \%$ of polyaniline is deposited on the carbon [122]. It has been further reported that the composite made from natural bamboo and polyaniline attained high energy density of $47.5 \mathrm{Wh} \mathrm{kg}^{-1}$, demonstrating that the composite was a good candidate for supercapacitor [123]. 
2.4. Activated Carbon/Carbon Nanotubes Composites. The electrochemical performance of activated carbon derived from biomass when composited with carbon nanotube (CNTs) has also been investigated. A coconut shell derived activated carbon was composited with CNTs. The capacitance of the coconut derived activated carbon alone was $92 \mathrm{~F} \mathrm{~g}^{-1}$, while that of carbon nanotube alone was $25 \mathrm{~F} \mathrm{~g}^{-1}$. However, when the two were composited, the capacitance decreased to 88 and $50 \mathrm{~F} \mathrm{~g}^{-1}$ at 15 and 50 wt.\% CNTs content, respectively [124]. The test was conducted in the nonaqueous electrolyte $\left(\mathrm{NEt}_{4} \mathrm{BF}_{4} 1.5 \mathrm{M}\right.$ in acetonitrile). These results imply that CNTs are not good for composites.

A carbon nanotube/self-adhesive carbon grain composite has been studied by Farma and coworkers [125]. The carbon grains were derived from oil palm empty fruit bunch fibers of different palm species. The specific capacitance obtained was 55,77 , and $85 \mathrm{~F} \mathrm{~g}^{-1}$ for composites carbonized at 600 , 700 , and $800^{\circ} \mathrm{C}$. The composite exhibited BET surface area of 434,415 , and $485 \mathrm{~m}^{2} \mathrm{~g}^{-1}$, though both the surface area and specific capacitance decreased when the CNTs were added; the equivalent series resistance (ESR) decreased by a factor of around 84, which in turn increased the power density as low ESR increases conductivity. Also specific capacitance fading was reduced significantly.

Porous structures from activated carbon, carbon aerogels, carbon nanotubes, and composites favor the accessibility of ions in an electrode. However, the type of an electrolyte used which is not the main focus of our review has significant effect. Aqueous, nonaqueous, and organic electrolytes are the mostly used electrolytes in energy storages.

\section{Conclusion}

In this review, different carbon forms produced from various biomass have been discussed. It has been shown that the capacitance and energy density of biomass based supercapacitor electrode depend on carbon nanostructures produced from individual carbon precursor. The influence of the pore structure (size and distribution), surface area, and heteroatoms present on the carbon has been discussed. From the perspective of this review, the following conclusions were drawn:

(1) The variation of physical characteristics not only necessitates finding new materials for supercapacitor electrodes but also argues for improvement of already studied materials be it through method of preparation or compositing with other materials.

(2) Though hydrothermal treatment route of producing carbonaceous material for supercapacitor electrode seems to be more efficient, the high temperatures and pressure involved increase the cost. Therefore, there is a need to search for catalysts to lower reaction temperature.

(3) Most biomass derived electrodes have been demonstrating high cyclic capability; thus promising future commercial use.
(4) The gravimetric capacitance attained by majority of the biomass derived carbon materials is not high enough; thus there is a need for compositing with other materials to improve the capacitance and energy density. The synergetic effect between metal oxides and biomass derived carbon needed to be optimized as the oxide contributes in the composite by providing high capacitance, while carbon ensures high conductivity and good rate capability.

(5) Despite the achievements in synthesis of biomass derived carbon materials for supercapacitors, an optimization of the structure of materials is desirable to increase both gravimetric capacitance and volumetric capacitance.

(6) The hydrothermal, ionothermal, and salt carbonization methods have shown high suitability in synthesizing of porous carbon materials; besides, a combination of methods may be suggested for further enhancement of the materials and energy storage devices.

\section{Competing Interests}

The authors declare that there are no competing interests regarding the publication of this paper.

\section{References}

[1] M. S. Halper and J. C. Ellenbogen, Supercapacitors: A Brief Overview, The MITRE Corporation, Mclean, Va, USA, 2006.

[2] L. L. Zhang and X. S. Zhao, "Carbon-based materials as supercapacitor electrodes," Chemical Society Reviews, vol. 38, no. 9, pp. 2520-2531, 2009.

[3] A. Burke, "Ultracapacitors: why, how, and where is the technology," Journal of Power Sources, vol. 91, no. 1, pp. 37-50, 2000.

[4] B. E. Conway, Electrochemical Supercapacitors: Scientific Fundamentals and Technological Applications, Springer US, Boston, Mass, USA, 1999.

[5] M. Winter and R. J. Brodd, "What are batteries, fuel cells, and supercapacitors?" Chemical Reviews, vol. 104, no. 10, pp. 42454270, 2004.

[6] J. R. Miller and A. F. Burke, "Electrochemical capacitors: challenges and opportunities for real-world applications," The Electrochemical Society Interface, vol. 17, no. 1, pp. 53-57, 2008.

[7] V. V. N. Obreja, "On the performance of supercapacitors with electrodes based on carbon nanotubes and carbon activated material-a review," Physica E: Low-Dimensional Systems and Nanostructures, vol. 40, no. 7, pp. 2596-2605, 2008.

[8] P. Simon and Y. Gogotsi, "Materials for electrochemical capacitors," Nature Materials, vol. 7, no. 11, pp. 845-854, 2008.

[9] F. Béguin, V. Presser, A. Balducci, and E. Frackowiak, "Carbons and electrolytes for advanced supercapacitors," Advanced Materials, vol. 26, no. 14, pp. 2219-2251, 2014.

[10] E. Frackowiak and F. Béguin, "Carbon materials for the electrochemical storage of energy in capacitors," Carbon, vol. 39, no. 6, pp. 937-950, 2001.

[11] C. Bouchelta, M. S. Medjram, O. Bertrand, and J.-P. Bellat, "Preparation and characterization of activated carbon from date 
stones by physical activation with steam," Journal of Analytical and Applied Pyrolysis, vol. 82, no. 1, pp. 70-77, 2008.

[12] M. L. Sekirifa, M. Hadj-Mahammed, S. Pallier, L. Baameur, D. Richard, and A. H. Al-Dujaili, "Preparation and characterization of an activated carbon from a date stones variety by physical activation with carbon dioxide," Journal of Analytical and Applied Pyrolysis, vol. 99, pp. 155-160, 2013.

[13] K. Sun and J. Chun Jiang, "Preparation and characterization of activated carbon from rubber-seed shell by physical activation with steam," Biomass and Bioenergy, vol. 34, no. 4, pp. 539-544, 2010.

[14] M. Sevilla and R. Mokaya, "Energy storage applications of activated carbons: supercapacitors and hydrogen storage," Energy \& Environmental Science, vol. 7, no. 4, pp. 1250-1280, 2014.

[15] Y. Sudaryanto, S. B. Hartono, W. Irawaty, H. Hindarso, and S. Ismadji, "High surface area activated carbon prepared from cassava peel by chemical activation," Bioresource Technology, vol. 97, no. 5, pp. 734-739, 2006.

[16] M. Olivares-Marín, C. Fernández-González, A. Macías-García, and V. Gómez-Serrano, "Preparation of activated carbons from cherry stones by activation with potassium hydroxide," Applied Surface Science, vol. 252, no. 17, pp. 5980-5983, 2006.

[17] N. Bagheri and J. Abedi, "Preparation of high surface area activated carbon from corn by chemical activation using potassium hydroxide," Chemical Engineering Research and Design, vol. 87, no. 8, pp. 1059-1064, 2009.

[18] J. Wang and S. Kaskel, "KOH activation of carbon-based materials for energy storage," Journal of Materials Chemistry, vol. 22, no. 45, pp. 23710-23725, 2012.

[19] K. Babel and K. Jurewicz, "KOH activated carbon fabrics as supercapacitor material," Journal of Physics and Chemistry of Solids, vol. 65, no. 2-3, pp. 275-280, 2004.

[20] R.-L. Tseng, "Mesopore control of high surface area $\mathrm{NaOH}-$ activated carbon," Journal of Colloid and Interface Science, vol. 303, no. 2, pp. 494-502, 2006.

[21] R.-L. Tseng, "Physical and chemical properties and adsorption type of activated carbon prepared from plum kernels by $\mathrm{NaOH}$ activation," Journal of Hazardous Materials, vol. 147, no. 3, pp. 1020-1027, 2007.

[22] J. Laine, A. Calafat, and M. labady, "Preparation and characterization of activated carbons from coconut shell impregnated with phosphoric acid," Carbon, vol. 27, no. 2, pp. 191-195, 1989.

[23] M. Molina-Sabio, F. RodRíguez-Reinoso, F. Caturla, and M. J. Sellés, "Porosity in granular carbons activated with phosphoric acid," Carbon, vol. 33, no. 8, pp. 1105-1113, 1995.

[24] Q.-S. Liu, T. Zheng, P. Wang, and L. Guo, "Preparation and characterization of activated carbon from bamboo by microwaveinduced phosphoric acid activation," Industrial Crops and Products, vol. 31, no. 2, pp. 233-238, 2010.

[25] V. Subramanian, C. Luo, A. M. Stephan, K. S. Nahm, S. Thomas, and B. Wei, "Supercapacitors from activated carbon derived from banana fibers," Journal of Physical Chemistry C, vol. 111, no. 20, pp. 7527-7531, 2007.

[26] I. A. W. Tan, A. L. Ahmad, and B. H. Hameed, "Preparation of activated carbon from coconut husk: optimization study on removal of 2,4,6-trichlorophenol using response surface methodology," Journal of Hazardous Materials, vol. 153, no. 1-2, pp. 709-717, 2008.

[27] F. T. Ademiluyi and E. O. David-West, "Effect of chemical activation on the adsorption of heavy metals using activated carbons from waste materials," ISRN Chemical Engineering, vol. 2012, Article ID 674209, 5 pages, 2012.
[28] P. Simon, P. L. Taberna, and F. Béguin, "Electrical doublelayer capacitors and carbons for EDLCs," in Supercapacitors: Materials, Systems, and Applications, pp. 131-165, Wiley-VCH, 2013.

[29] T. Pagketanang, A. Artnaseaw, P. Wongwicha, and M. Thabuot, "Microporous activated carbon from $\mathrm{KOH}$-activation of rubber seed-shells for application in capacitor electrode," Energy Procedia, vol. 79, pp. 651-656, 2015.

[30] C. Liang, Z. Li, and S. Dai, "Mesoporous carbon materials: synthesis and modification," Angewandte Chemie-International Edition, vol. 47, no. 20, pp. 3696-3717, 2008.

[31] C. Largeot, C. Portet, J. Chmiola, P.-L. Taberna, Y. Gogotsi, and P. Simon, "Relation between the ion size and pore size for an electric double-layer capacitor," Journal of the American Chemical Society, vol. 130, no. 9, pp. 2730-2731, 2008.

[32] T. E. Rufford, D. Hulicova-Jurcakova, Z. Zhu, and G. Q. Lu, "Nanoporous carbon electrode from waste coffee beans for high performance supercapacitors," Electrochemistry Communications, vol. 10, no. 10, pp. 1594-1597, 2008.

[33] X. Li, W. Xing, S. Zhuo et al., "Preparation of capacitor's electrode from sunflower seed shell," Bioresource Technology, vol. 102, no. 2, pp. 1118-1123, 2011.

[34] T. E. Rufford, D. Hulicova-Jurcakova, K. Khosla, Z. Zhu, and G. Q. Lu, "Microstructure and electrochemical double-layer capacitance of carbon electrodes prepared by zinc chloride activation of sugar cane bagasse," Journal of Power Sources, vol. 195, no. 3, pp. 912-918, 2010.

[35] M. R. Jisha, Y. J. Hwang, J. S. Shin et al., "Electrochemical characterization of supercapacitors based on carbons derived from coffee shells," Materials Chemistry and Physics, vol. 115, no. 1, pp. 33-39, 2009.

[36] M. Biswal, A. Banerjee, M. Deo, and S. Ogale, "From dead leaves to high energy density supercapacitors," Energy and Environmental Science, vol. 6, no. 4, pp. 1249-1259, 2013.

[37] M. S. Balathanigaimani, W.-G. Shim, M.-J. Lee, C. Kim, J.W. Lee, and H. Moon, "Highly porous electrodes from novel corn grains-based activated carbons for electrical double layer capacitors," Electrochemistry Communications, vol. 10, no. 6, pp. 868-871, 2008.

[38] X. Xia, H. Liu, L. Shi, and Y. He, “Tobacco stem-based activated carbons for high performance supercapacitors," Journal of Materials Engineering and Performance, vol. 21, no. 9, pp. 19561961, 2012.

[39] M. Chen, X. Kang, T. Wumaier et al., "Preparation of activated carbon from cotton stalk and its application in supercapacitor," Journal of Solid State Electrochemistry, vol. 17, no. 4, pp. 10051012, 2013.

[40] R. Wang, P. Wang, X. Yan, J. Lang, C. Peng, and Q. Xue, "Promising porous carbon derived from celtuce leaves with outstanding supercapacitance and $\mathrm{CO}_{2}$ capture performance," ACS Applied Materials \& Interfaces, vol. 4, no. 11, pp. 5800-5806, 2012.

[41] X. He, P. Ling, M. Yu, X. Wang, X. Zhang, and M. Zheng, "Rice husk-derived porous carbons with high capacitance by $\mathrm{ZnCl}_{2}$ activation for supercapacitors," Electrochimica Acta, vol. 105, pp. 635-641, 2013.

[42] C. Kim, J.-W. Lee, J.-H. Kim, and K.-S. Yang, "Feasibility of bamboo-based activated carbons for an electrochemical supercapacitor electrode," Korean Journal of Chemical Engineering, vol. 23, no. 4, pp. 592-594, 2006.

[43] D. Kalpana, S. H. Cho, S. B. Lee, Y. S. Lee, R. Misra, and N. G. Renganathan, "Recycled waste paper-a new source of raw 
material for electric double-layer capacitors," Journal of Power Sources, vol. 190, no. 2, pp. 587-591, 2009.

[44] J. Mi, X.-R. Wang, R.-J. Fan, W.-H. Qu, and W.-C. Li, "Coconutshell-based porous carbons with a tunable micro/mesopore ratio for high-performance supercapacitors," Energy and Fuels, vol. 26, no. 8, pp. 5321-5329, 2012.

[45] C.-C. Hu, C.-C. Wang, F.-C. Wu, and R.-L. Tseng, "Characterization of pistachio shell-derived carbons activated by a combination of $\mathrm{KOH}$ and $\mathrm{CO}_{2}$ for electric double-layer capacitors," Electrochimica Acta, vol. 52, no. 7, pp. 2498-2505, 2007.

[46] C. Peng, X.-B. Yan, R.-T. Wang, J.-W. Lang, Y.-J. Ou, and Q.J. Xue, "Promising activated carbons derived from waste tealeaves and their application in high performance supercapacitors electrodes," Electrochimica Acta, vol. 87, pp. 401-408, 2013.

[47] F. Kurniawan, M. Wongso, A. Ayucitra et al., "Carbon microsphere from water hyacinth for supercapacitor electrode," Journal of the Taiwan Institute of Chemical Engineers, vol. 47, pp. 197201, 2015.

[48] S. T. Senthilkumar, R. K. Selvan, Y. S. Lee, and J. S. Melo, “Electric double layer capacitor and its improved specific capacitance using redox additive electrolyte," Journal of Materials Chemistry A, vol. 1, no. 4, pp. 1086-1095, 2013.

[49] K. Wu, B. Gao, J. Su et al., "Large and porous carbon sheets derived from water hyacinth for high-performance supercapacitors," RSC Advances, vol. 6, no. 36, pp. 29996-30003, 2016.

[50] Y.-Q. Zhao, M. Lu, P.-Y. Tao et al., "Hierarchically porous and heteroatom doped carbon derived from tobacco rods for supercapacitors," Journal of Power Sources, vol. 307, pp. 391-400, 2016.

[51] H. Wang, Z. Xu, A. Kohandehghan et al., "Interconnected carbon nanosheets derived from hemp for ultrafast supercapacitors with high energy," ACS Nano, vol. 7, no. 6, pp. 5131-5141, 2013.

[52] A. Elmouwahidi, Z. Zapata-Benabithe, F. Carrasco-Marín, and C. Moreno-Castilla, "Activated carbons from $\mathrm{KOH}$-activation of argan (Argania spinosa) seed shells as supercapacitor electrodes," Bioresource Technology, vol. 111, pp. 185-190, 2012.

[53] J. Li, G. Zan, and Q. Wu, "Nitrogen and sulfur self-doped porous carbon from brussel sprouts as electrode materials for high stable supercapacitors," RSC Advances, vol. 6, no. 62, pp. 5746457472, 2016.

[54] H. Shi, "Activated carbons and double layer capacitance," Electrochimica Acta, vol. 41, no. 10, pp. 1633-1639, 1996.

[55] D. Bhattacharjya and J.-S. Yu, "Activated carbon made from cow dung as electrode material for electrochemical double layer capacitor," Journal of Power Sources, vol. 262, pp. 224-231, 2014.

[56] W. Huang, H. Zhang, Y. Huang, W. Wang, and S. Wei, "Hierarchical porous carbon obtained from animal bone and evaluation in electric double-layer capacitors," Carbon, vol. 49, no. 3, pp. 838-843, 2011.

[57] P. A. Goodman, H. Li, Y. Gao, Y. F. Lu, J. D. Stenger-Smith, and J. Redepenning, "Preparation and characterization of high surface area, high porosity carbon monoliths from pyrolyzed bovine bone and their performance as supercapacitor electrodes," Carbon, vol. 55, pp. 291-298, 2013.

[58] Z. Li, L. Zhang, B. S. Amirkhiz et al., "Carbonized chicken eggshell membranes with $3 \mathrm{D}$ architectures as high-performance electrode materials for supercapacitors," Advanced Energy Materials, vol. 2, no. 4, pp. 431-437, 2012.

[59] W. Qian, F. Sun, Y. Xu et al., "Human hair-derived carbon flakes for electrochemical supercapacitors," Energy \& Environmental Science, vol. 7, no. 1, pp. 379-386, 2014.
[60] W. Chen, H. Zhang, Y. Huang, and W. Wang, "A fish scale based hierarchical lamellar porous carbon material obtained using a natural template for high performance electrochemical capacitors," Journal of Materials Chemistry, vol. 20, no. 23, pp. 4773-4775, 2010.

[61] Q. Wang, Q. Cao, X. Wang, B. Jing, H. Kuang, and L. Zhou, "A high-capacity carbon prepared from renewable chicken feather biopolymer for supercapacitors," Journal of Power Sources, vol. 225, pp. 101-107, 2013.

[62] J. Li, S. Ma, L. Cheng, and Q. Wu, "Egg yolk-derived threedimensional porous carbon for stable electrochemical supercapacitors," Materials Letters, vol. 139, pp. 429-432, 2015.

[63] J. Chmiola, G. Yushin, Y. Gogotsi, C. Portet, P. Simon, and P. L. Taberna, "Anomalous increase in carbon capacitance at pore sizes less than 1 nanometer," Science, vol. 313, no. 5794, pp. 1760 1763, 2006.

[64] W. Si, J. Zhou, S. Zhang, S. Li, W. Xing, and S. Zhuo, "Tunable $\mathrm{N}$-doped or dual N, S-doped activated hydrothermal carbons derived from human hair and glucose for supercapacitor applications," Electrochimica Acta, vol. 107, pp. 397-405, 2013.

[65] Q. Wang, J. Yan, and Z. Fan, "Carbon materials for high volumetric performance supercapacitors: design, progress, challenges and opportunities," Energy \& Environmental Science, vol. 9, no. 3, pp. 729-762, 2016.

[66] Q. Xie, R. Bao, A. Zheng et al., "Sustainable low-cost green electrodes with high volumetric capacitance for aqueous symmetric supercapacitors with high energy density," ACS Sustainable Chemistry and Engineering, vol. 4, no. 3, pp. 1422-1430, 2016.

[67] G. A. Ferrero, A. B. Fuertes, and M. Sevilla, "From Soybean residue to advanced supercapacitors," Scientific Reports, vol. 5, Article ID 16618, 2015.

[68] C. Long, X. Chen, L. Jiang, L. Zhi, and Z. Fan, "Porous layerstacking carbon derived from in-built template in biomass for high volumetric performance supercapacitors," Nano Energy, vol. 12, pp. 141-151, 2015.

[69] C. Long, L. Jiang, X. Wu et al., "Facile synthesis of functionalized porous carbon with three-dimensional interconnected pore structure for high volumetric performance supercapacitors," Carbon, vol. 93, pp. 412-420, 2015.

[70] M. D. Stoller and R. S. Ruoff, "Best practice methods for determining an electrode material's performance for ultracapacitors," Energy \& Environmental Science, vol. 3, no. 9, pp. 1294-1301, 2010.

[71] M. Seredych, D. Hulicova-Jurcakova, G. Q. Lu, and T. J. Bandosz, "Surface functional groups of carbons and the effects of their chemical character, density and accessibility to ions on electrochemical performance," Carbon, vol. 46, no. 11, pp. 1475$1488,2008$.

[72] Y. Zhao, M. Liu, X. Deng et al., "Nitrogen-functionalized microporous carbon nanoparticles for high performance supercapacitor electrode," Electrochimica Acta, vol. 153, pp. 448-455, 2015.

[73] P.-Z. Cheng and H. Teng, "Electrochemical responses from surface oxides present on $\mathrm{HNO}_{3}$-treated carbons," Carbon, vol. 41, no. 11, pp. 2057-2063, 2003.

[74] Z. Li, Z. Xu, X. Tan et al., "Mesoporous nitrogen-rich carbons derived from protein for ultra-high capacity battery anodes and supercapacitors," Energy \& Environmental Science, vol. 6, no. 3, pp. 871-878, 2013.

[75] D. Zhang, L. Zheng, Y. Ma et al., "Synthesis of nitrogenand sulfur-codoped 3D cubic-ordered mesoporous carbon 
with superior performance in supercapacitors," ACS Applied Materials \& Interfaces, vol. 6, no. 4, pp. 2657-2665, 2014.

[76] M. Seredych and T. J. Bandosz, "S-doped micro/mesoporous carbon-graphene composites as efficient supercapacitors in alkaline media," Journal of Materials Chemistry A, vol. 1, no. 38, pp. 11717-11727, 2013.

[77] E. G. Calvo, N. Ferrera-Lorenzo, J. A. Menéndez, and A. Arenillas, "Microwave synthesis of micro-mesoporous activated carbon xerogels for high performance supercapacitors," Microporous and Mesoporous Materials, vol. 168, pp. 206-212, 2013.

[78] J. M. V. Nabais, P. J. M. Carrott, M. M. L. R. Carrott, and J. A. Menéndez, "Preparation and modification of activated carbon fibres by microwave heating," Carbon, vol. 42, no. 7, pp. 13151320, 2004.

[79] P. Puligundla, S. Oh, and C. Mok, "Microwave-assisted pretreatment technologies for the conversion of lignocellulosic biomass to sugars and ethanol: a review," Carbon Letters, vol. 17, no. 1, pp. $1-10,2016$.

[80] M. Sevilla and A. B. Fuertes, "The production of carbon materials by hydrothermal carbonization of cellulose," Carbon, vol. 47, no. 9, pp. 2281-2289, 2009.

[81] L. Zhang, Q. Wang, B. Wang, G. Yang, L. A. Lucia, and J. Chen, "Hydrothermal carbonization of corncob residues for hydrochar production," Energy \& Fuels, vol. 29, no. 2, pp. 872876, 2015.

[82] L. Zhang, S. Liu, B. Wang, Q. Wang, G. Yang, and J. Chen, "Effect of residence time on hydrothermal carbonization of corn cob residual," BioResources, vol. 10, no. 3, 2015.

[83] D. Kalderis, M. S. Kotti, A. Méndez, and G. Gascó, “Characterization of hydrochars produced by hydrothermal carbonization of rice husk," Solid Earth, vol. 5, no. 1, pp. 477-483, 2014.

[84] A. Jain, C. Xu, S. Jayaraman, R. Balasubramanian, J. Y. Lee, and M. P. Srinivasan, "Mesoporous activated carbons with enhanced porosity by optimal hydrothermal pre-treatment of biomass for supercapacitor applications," Microporous and Mesoporous Materials, vol. 218, pp. 55-61, 2015.

[85] D. C. S. Azevedo, J. C. S. Araújo, M. Bastos-Neto, A. E. B. Torres, E. F. Jaguaribe, and C. L. Cavalcante, "Microporous activated carbon prepared from coconut shells using chemical activation with zinc chloride," Microporous and Mesoporous Materials, vol. 100, no. 1-3, pp. 361-364, 2007.

[86] S. E. Elaigwu and G. M. Greenway, "Microwave-assisted and conventional hydrothermal carbonization of lignocellulosic waste material: comparison of the chemical and structural properties of the hydrochars," Journal of Analytical and Applied Pyrolysis, vol. 118, pp. 1-8, 2015.

[87] A. Jain, R. Balasubramanian, and M. Srinivasan, "Hydrothermal pre-treatment of biomass waste for high surface area mesoporous activated carbons," in Proceedings of the Asia Pacific Confederation of Chemical Engineering Congress: APCChE 2015, Incorporating (CHEMECA '15), p. 981, Engineers Australia, 2015.

[88] F.-C. Wu, R.-L. Tseng, C.-C. Hu, and C.-C. Wang, "Effects of pore structure and electrolyte on the capacitive characteristics of steam- and $\mathrm{KOH}$-activated carbons for supercapacitors," Journal of Power Sources, vol. 144, no. 1, pp. 302-309, 2005.

[89] G. Gryglewicz, J. Machnikowski, E. Lorenc-Grabowska, G. Lota, and E. Frackowiak, "Effect of pore size distribution of coal-based activated carbons on double layer capacitance," Electrochimica Acta, vol. 50, no. 5, pp. 1197-1206, 2005.
[90] N. Syarif and M. C. Pardede, "Hydrothermal assisted microwave pyrolysis of water hyacinth for electrochemical capacitors electrodes," Concrete Structures in Thailand Hydrothermal Assisted Microwave Pyrolysis of Water Hyacinth for Electrochemical Capacitors Electrodes Group Technology Paves the Road for Automation Effect of Laser Priming on Accumulation of Free Proline in Spring, p. 95, 2013.

[91] Y. Chang, M. Antonietti, and T.-P. Fellinger, "Synthesis of nanostructured carbon through ionothermal carbonization of common organic solvents and solutions," Angewandte Chemie-International Edition, vol. 54, no. 18, pp. 5507-5512, 2015.

[92] J. Pampel, C. Denton, and T.-P. Fellinger, "Glucose derived ionothermal carbons with tailor-made porosity," Carbon, vol. 107, pp. 288-296, 2016.

[93] X.-X. Lin, B. Tan, L. Peng, Z.-F. Wu, and Z.-L. Xie, "Ionothermal synthesis of microporous and mesoporous carbon aerogels from fructose as electrode materials for supercapacitors," Journal of Materials Chemistry A, vol. 4, no. 12, pp. 4497-4505, 2016.

[94] Z.-L. Xie, R. J. White, J. Weber, A. Taubert, and M. M. Titirici, "Hierarchical porous carbonaceous materials via ionothermal carbonization of carbohydrates," Journal of Materials Chemistry, vol. 21, no. 20, pp. 7434-7442, 2011.

[95] P. Zhang, Y. Gong, Z. Wei et al., "Updating biomass into functional carbon material in ionothermal manner," ACS Applied Materials \& Interfaces, vol. 6, no. 15, pp. 12515-12522, 2014.

[96] F. Guo and Z. Fang, "Shape-controlled synthesis of activated bio-chars by surfactant-templated ionothermal carbonization in acidic ionic liquid and activation with carbon dioxide," BioResources, vol. 9, no. 2, pp. 3369-3383, 2014.

[97] X. Liu, C. Giordano, and M. Antonietti, "A facile molten-salt route to graphene synthesis," Small, vol. 10, no. 1, pp. 193-200, 2014.

[98] B. Lu, L. Hu, H. Yin, W. Xiao, and D. Wang, “One-step molten salt carbonization (MSC) of firwood biomass for capacitive carbon," RSC Advances, vol. 6, no. 108, pp. 106485-106490, 2016.

[99] X. Deng, B. Zhao, L. Zhu, and Z. Shao, "Molten salt synthesis of nitrogen-doped carbon with hierarchical pore structures for use as high-performance electrodes in supercapacitors," Carbon, vol. 93, pp. 48-58, 2015.

[100] H. Yin, B. Lu, Y. Xu et al., "Harvesting capacitive carbon by carbonization of waste biomass in molten salts," Environmental Science and Technology, vol. 48, no. 14, pp. 8101-8108, 2014.

[101] B. Lu, L. Hu, H. Yin, X. Mao, W. Xiao, and D. Wang, "Preparation and application of capacitive carbon from bamboo shells by one step molten carbonates carbonization," International Journal of Hydrogen Energy, vol. 41, no. 41, pp. 18713-18720, 2016.

[102] B. Lu, J. Zhou, Y. Song, H. Wang, W. Xiao, and D. Wang, "Molten-salt treatment of waste biomass for preparation of carbon with enhanced capacitive properties and electrocatalytic activity towards oxygen reduction," Faraday Discussions, vol. 190, pp. 147-159, 2016.

[103] A. G. Pandolfo and A. F. Hollenkamp, "Carbon properties and their role in supercapacitors," Journal of Power Sources, vol. 157, no. 1, pp. 11-27, 2006.

[104] U. Fischer, R. Saliger, V. Bock, R. Petricevic, and J. Fricke, "Carbon aerogels as electrode material in supercapacitors," Journal of Porous Materials, vol. 4, no. 4, pp. 281-285, 1997.

[105] P. Cheng, T. Li, H. Yu, L. Zhi, Z. Liu, and Z. Lei, "Biomassderived carbon fiber aerogel as a binder-free electrode for highrate supercapacitors," Journal of Physical Chemistry C, vol. 120, no. 4, pp. 2079-2086, 2016. 
[106] X.-L. Wu, T. Wen, H.-L. Guo, S. Yang, X. Wang, and A.-W. $\mathrm{Xu}$, "Biomass-derived sponge-like carbonaceous hydrogels and aerogels for supercapacitors," ACS Nano, vol. 7, no. 4, pp. 35893597, 2013.

[107] P. Hao, Z. Zhao, J. Tian et al., "Hierarchical porous carbon aerogel derived from bagasse for high performance supercapacitor electrode," Nanoscale, vol. 6, no. 20, pp. 12120-12129, 2014.

[108] Y. Ren, J. Zhang, Q. Xu et al., "Biomass-derived threedimensional porous $\mathrm{N}$-doped carbonaceous aerogel for efficient supercapacitor electrodes," RSC Advances, vol. 4, no. 45, pp. 23412-23419, 2014.

[109] D. Yang, Application of Nanocomposites for Supercapacitors: Characteristics and Properties, INTECH Open Access, 2012.

[110] X. Wu, W. Xiong, Y. Chen et al., "High-rate supercapacitor utilizing hydrous ruthenium dioxide nanotubes," Journal of Power Sources, vol. 294, pp. 88-93, 2015.

[111] M.-S. Wu, Y.-A. Huang, C.-H. Yang, and J.-J. Jow, "Electrodeposition of nanoporous nickel oxide film for electrochemical capacitors," International Journal of Hydrogen Energy, vol. 32, no. 17, pp. 4153-4159, 2007.

[112] X. Zhang, X. Sun, H. Zhang, D. Zhang, and Y. Ma, "Microwaveassisted reflux rapid synthesis of $\mathrm{MnO} 2$ nanostructures and their application in supercapacitors," Electrochimica Acta, vol. 87, pp. 637-644, 2013.

[113] N. Syarif, I. A. Tribidasari, and W. Wibowo, "Binder-less activated carbon electrode from gelam wood for use in supercapacitors," Journal of Electrochemical Science and Engineering, vol. 3, no. 2, pp. 37-45, 2013.

[114] M. Zhi, C. Xiang, J. Li, M. Li, and N. Wu, "Nanostructured carbon-metal oxide composite electrodes for supercapacitors: a review," Nanoscale, vol. 5, no. 1, pp. 72-88, 2013.

[115] C. Lin, J. A. Ritter, and B. N. Popov, "Development of carbonmetal oxide supercapacitors from sol-gel derived carbonruthenium xerogels," Journal of the Electrochemical Society, vol. 146, no. 9, pp. 3155-3160, 1999.

[116] H. Kim and B. N. Popov, "Characterization of hydrous ruthenium oxide/carbon nanocomposite supercapacitors prepared by a colloidal method," Journal of Power Sources, vol. 104, no. 1, pp. 52-61, 2002.

[117] K. Lota, A. Sierczynska, and G. Lota, "Supercapacitors based on nickel oxide/carbon materials composites," International Journal of Electrochemistry, vol. 2011, Article ID 321473, 6 pages, 2011.

[118] S. He and W. Chen, "Application of biomass-derived flexible carbon cloth coated with $\mathrm{MnO}_{2}$ nanosheets in supercapacitors," Journal of Power Sources, vol. 294, pp. 150-158, 2015.

[119] L. Wang, Y. Zheng, S. Chen et al., "Three-dimensional kenaf stem-derived porous carbon $/ \mathrm{MnO}_{2}$ for high-performance supercapacitors," Electrochimica Acta, vol. 135, pp. 380-387, 2014.

[120] W. Xiong, Y. Gao, X. Wu et al., "Composite of macroporous carbon with honeycomb-like structure from mollusc shell and $\mathrm{NiCo}_{2} \mathrm{O}_{4}$ nanowires for high-performance supercapacitor," ACS Applied Materials \& Interfaces, vol. 6, no. 21, pp. 1941619423, 2014

[121] Q. Wang, J.-L. Li, F. Gao, W.-S. Li, K.-Z. Wu, and X.-D. Wang, "Activated carbon coated with polyaniline as an electrode material in supercapacitors," New Carbon Materials, vol. 23, no. 3, pp. 275-280, 2008.

[122] Y.-R. Lin and H. Teng, "A novel method for carbon modification with minute polyaniline deposition to enhance the capacitance of porous carbon electrodes," Carbon, vol. 41, no. 14, pp. 28652871, 2003.

[123] X. Zhou, L. Li, S. Dong et al., "A renewable bamboo carbon/polyaniline composite for a high-performance supercapacitor electrode material," Journal of Solid State Electrochemistry, vol. 16, no. 3, pp. 877-882, 2012.

[124] P.-L. Taberna, G. Chevallier, P. Simon, D. Plée, and T. Aubert, "Activated carbon-carbon nanotube composite porous film for supercapacitor applications," Materials Research Bulletin, vol. 41, no. 3, pp. 478-484, 2006.

[125] R. Farma, M. Deraman, Awitdrus et al., "Physical and electrochemical properties of supercapacitor electrodes derived from carbon nanotube and biomass carbon," International Journal of Electrochemical Science, vol. 8, no. 1, pp. 257-273, 2013. 

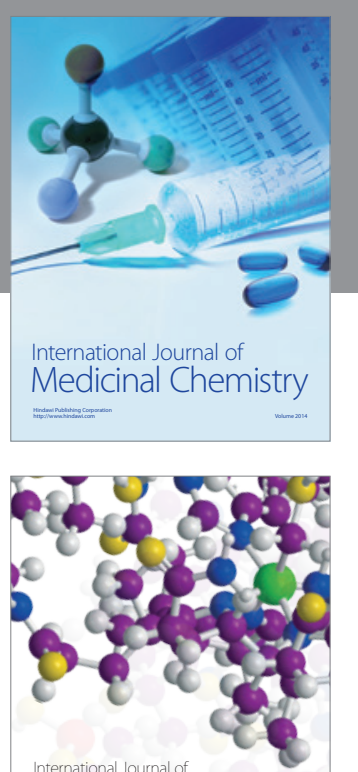

Carbohydrate Chemistry

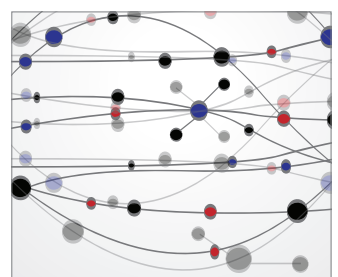

The Scientific World Journal
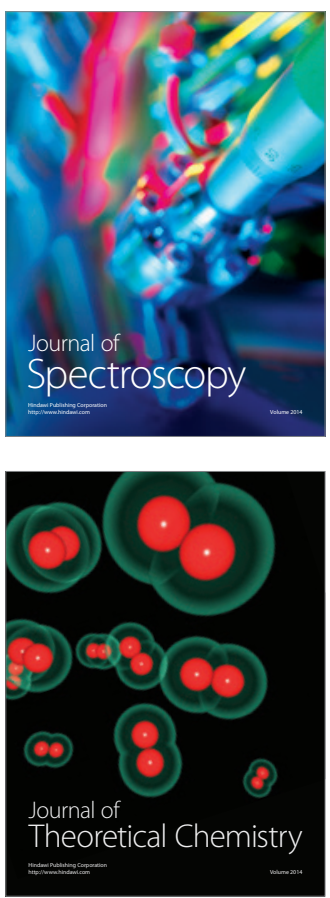
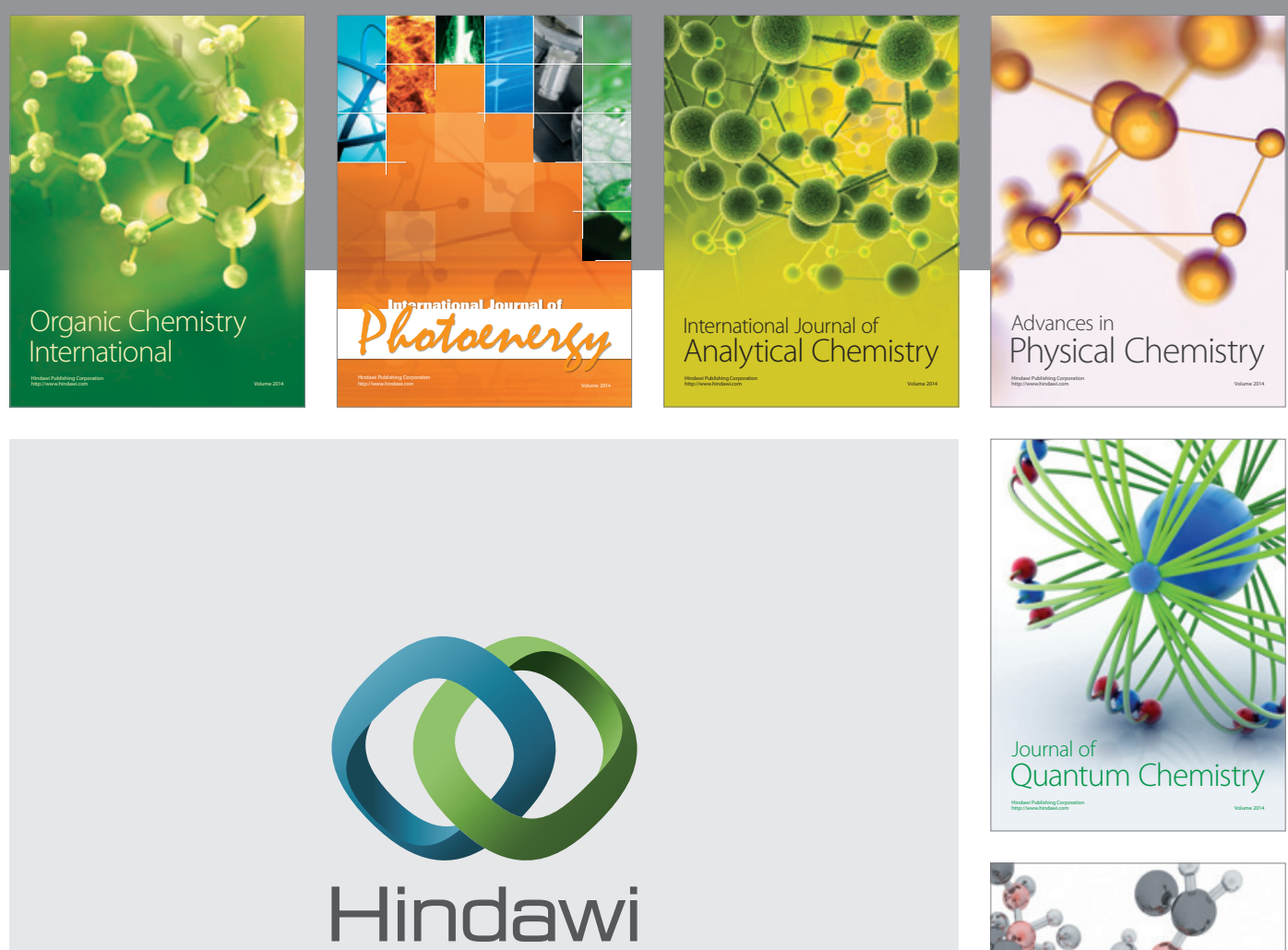

Submit your manuscripts at

https://www.hindawi.com

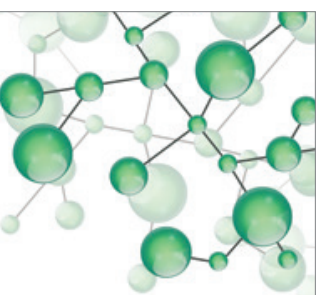

International Journal of

Inorganic Chemistry
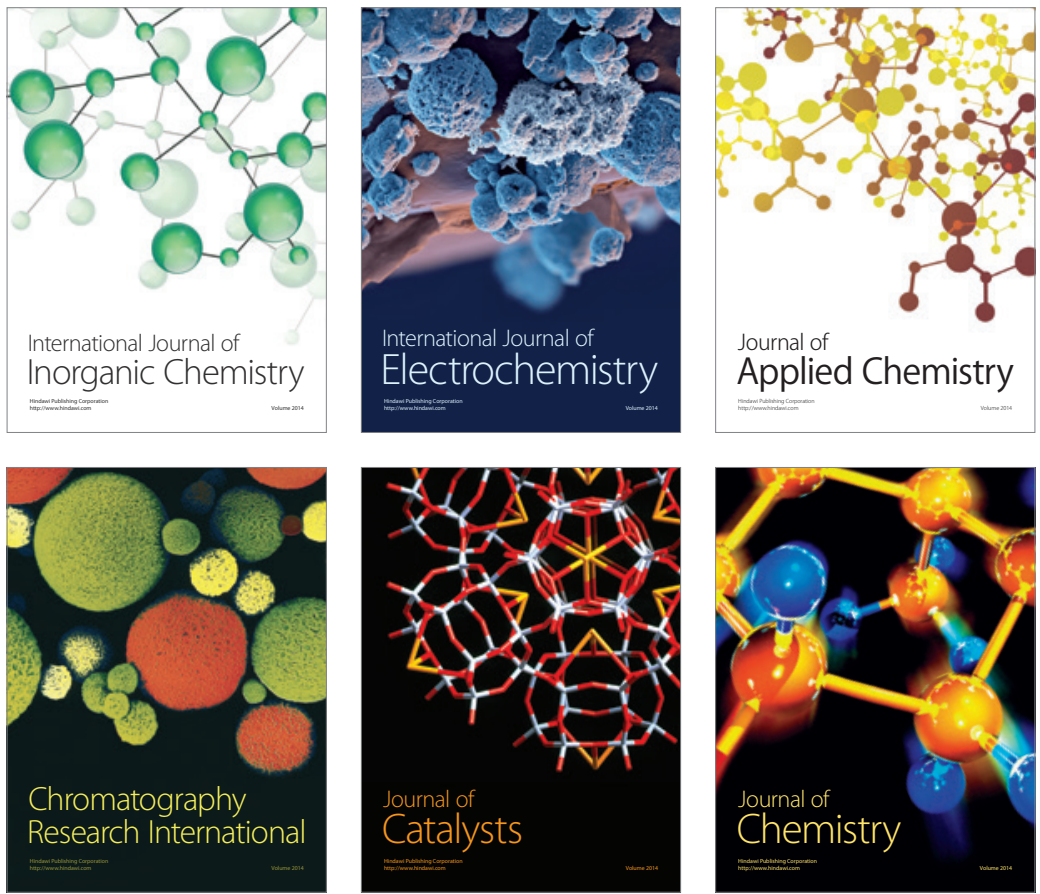

Journal of

Applied Chemistry
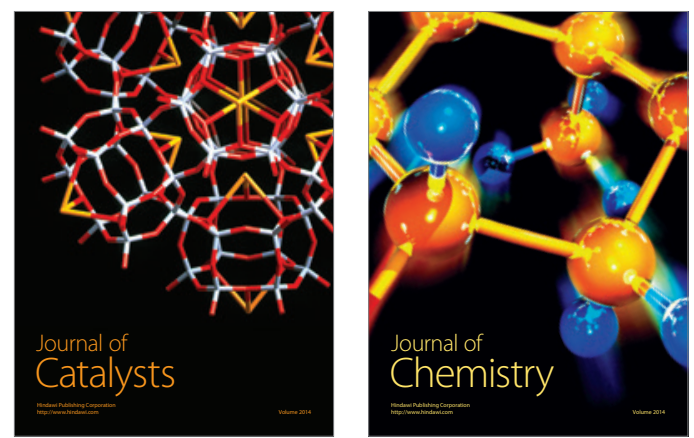
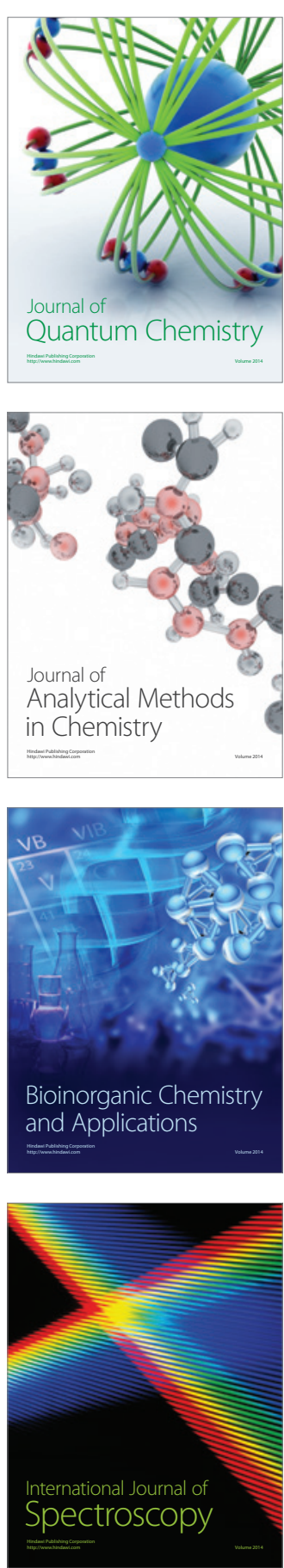